Proceedings of the 2018 International Scientific Conference 'Economic Sciences for Agribusiness and Rural Economy' No 1, Warsaw, 7-8 June 2018, pp. 376-382

\title{
EU FUNDS (RDP) AND THEIR IMPACT ON LOCAL DEVELOPMENT
}

\author{
Paweł Janulewicz, $\mathrm{PhD}^{1}$ \\ Faculty of Agrobioengineering, University of Life Sciences in Lublin
}

\begin{abstract}
The paper presents the results of research aimed at determining the impact of the use of EU funds on local development on the example of voivodeships. The first stage of the research was performed with the use of Hellwig's development model method. It was aimed at classifying individual voivodships and assigning them to one of four groups in terms of their level of development. The next stage was to check whether the examined features proving the level of local development are also related to the level of use of EU funds under RDP. In the third stage, the analysis of Ward clusters was used and answers were sought as to whether the units which are clustered together in terms of the level of use of EU funds are at the same time included in the same groups in terms of the level of local development.
\end{abstract}

Keywords: local development, Hellwig's method, Ward's method

JEL codes: $018, \mathrm{C} 10$

\section{INTRODUCTION AND THEORETICAL BACKGROUND}

The main objective of RDPs for 2014-2020 is 'to improve the competitiveness of agriculture, sustainable management of natural resources and climate action, and balanced territorial development of rural areas ${ }^{2}$. Nowadays, an increasing number of authors undertake to conduct research on the impact of the use of EU funds for agricultural development and, consequently, the development of a given territorial unit (Brzózka and Nurzyńska, 2002; Knieć, 2012; Piworowicz, 2015; Misztal, 2016; Nowak et al.,
2016; Sawicka and Borowy, 2007; Tomczak, 2009; Wójcik, 2011). The concept of local development is multidimensional, and therefore does not have a uniform definition. Currently, the main driving factor is considered to be the endogenous potential on which the dynamics of its development depends (Sobczyk, 2010). Under RDP 2014-2020, which directly affects the development of endogenous potential, public funds amounting to EUR 13,612,211,428 are planned to be used, including EUR 8,697,556,814 from the EU budget (EAFRD) and the remaining EUR $4,914,654,614$ from national contribution ${ }^{3}$. That is why it is so important to address this issue.

\footnotetext{
${ }^{1}$ Corresponding author: Dobrzańskiego 37, 20-262 Lublin, Poland, + 48814610061 (285 interphone), pawel.janlulewicz@ up.lublin.pl

${ }^{2}$ Ministerstwo Rolnictwa i Rozwoju Wsi [Ministry of Agriculture and Rural Development] webpage http://www.minrol. gov.pl/Wsparcie-rolnictwa/Program-Rozwoju-Obszarow-Wiejskich-2014-2020.

${ }^{3}$ Ibidem.
} 


\section{MATERIALS AND METHODS}

The substantive selection of factors characterising the level of local development was based on the study of literature (Kamińska and Janulewicz, 2009; Adamowicz and Janulewicz, 2012; Bujanowicz-Haraś et al., 2015; Adamowicz et al., 2016; Janulewicz and Janulewicz, 2016; Nowak, Janulewicz and Krukowski, 2016), and the level of use of EU funds was based on (Nowak et al., 2016). On this basis, 88 diagnostic variables characterising the level of local development and 22 variables describing the level of use of funds under RDP 2014-2020 were selected. Then, it was checked whether the variables meet formal criteria: they are measurable, complete and ensure comparability (Adamowicz et al., 2016). Taking into account statistical criteria, the so-called quasi-constant variables (for which the coefficient of variation did not exceed $11 \%$ ) were removed from the set, e.g.: the share of agricultural commodity production in total agricultural production $(V=4.50 \%)$. The next step was to eliminate overly correlated features, e.g. agricultural land in good agricultural condition with the total area of farms $(0.99)$. Ultimately, the paper adopted 27 features, on the basis of which the level of local development was determined.

The same procedure was adopted for the variables describing the level of use of EU funds under RDP. The variables characterised by a low coefficient of variation, e.g. Axis 1, were rejected from further analyses. Action 112: Setting up young farmers $(V=1 \%)$. Another reduction was the rejection of funds which were excessively correlated with each other, e.g. Axis 2. Action 221, 223. Afforestation of agricultural land and afforestation of non-agricultural land with Axis 2. Action 214: Agri-environmental programme for which the Pearson correlation coefficient was 0.89 . Out of 22 actions under RDP, 12 were used for further analyses after selection. At the same time, it is worth emphasising that information on the funds used was for the years 2014-2015, and the features describing local development - for 2016. It was assumed that the effects of the funds on local development could be observed only after a certain period of time.

The paper also uses cluster analysis, which allowed to bundle voivodeships which are most similar to each other and at the same time are as different as possible in terms of the level of use of EU funds under RDP. One of the hierarchical methods of grouping, i.e. the Ward's method, was used. The grouping of voivodeships was carried out using Statistica 13 software. The results of grouping using the Ward's method are presented in Figure 1.

Ultimately 39 diagnostic variables were selected for analysis: $x_{1}$ - slaughter livestock production - share of voivodeships in total slaughter livestock production (\%), $x_{2}$ - purchase of products per 1 ha of arable land - basic cereals $(\mathrm{kg}), x_{3}$ - purchase of products per 1 ha of arable land - potatoes $(\mathrm{kg}), x_{4}$ - purchase of products per 1 ha of arable land - cow's milk (1), $x_{5}$ - total income per capita (PLN), $x_{6}$ - outlays in the public sector per capita (PLN), $x_{7}$ - outlays in the private sector per capita (PLN), $x_{8}-$ gross value of fixed assets per capita (in PLN), $x_{9}$ - average usable area of 1 flat $\left(\mathrm{m}^{2}\right), x_{10}$ - registered unemployment (\%), $x_{11}$ - total use of NPK mineral fertilizers per 1 ha of arable land according to the new definition $(\mathrm{kg}), x_{12}-$ share of home gardens in the total area of the voivodeship (\%), $x_{13}$ - share of meadows and pastures according to the new definition in the total area of the voivodeship (\%), $x_{14}$ - share of perennial crops according to the new definition in the total area of the voivodeship (\%), $x_{15}$ - number of expressways and motorways per $1,000 \mathrm{~km}^{2}(\mathrm{~km}), x_{16}$ - number of trucks per 1,000 people (in pcs.), $x_{17}$ - number of motorcycles per 1,000 people (pcs.), $x_{18}$ - number of bike tracks per $10,000 \mathrm{~km}^{2}(\mathrm{~km}), x_{19}$ - number of bike tracks per 10,000 people $(\mathrm{km}), x_{20}$ - total length of railroads per $100 \mathrm{~km}^{2}(\mathrm{~km}), x_{21}$ - total length of railroads per 10,000 people $(\mathrm{km}), x_{22}$ - number of people using the sewage system (\%), $x_{23}$ - number of people using the gas pipeline (\%), $x_{24}$ - household gas consumption per capita $\left(\mathrm{m}^{3}\right), x_{25}$ - enrollment rate - basic vocational schools - age 16-18 years (\%), $x_{26}$ - gross enrollment rate - post-secondary schools, including colleges - age 19-21 (\%), $x_{27}$ - graduates of higher education institutions per 10,000 people (persons), $x_{28}-$ Axis 1 . Action 114 . Use of advisory services by farmers and forest holders (PLN per 1 beneficiary), $x_{29}-$ Axis 1. Action 121. Modernisation of agricultural holdings in forests (PLN per beneficiary), $x_{30}$ - Axis 1. Action 123. Increasing the added value of 
primary agricultural and forestry production of forests (in PLN per beneficiary), $x_{31}-$ Axis 1 . Action 126. Restoring agricultural production potential of forests (PLN per 1 beneficiary), $x_{32}-$ Axis 1 . Action 132. Participation of farmers in forest food quality schemes (PLN per 1 beneficiary), $\mathrm{x}_{33}$ - Axis 1 . Action 133. Forest information and promotion activities (PLN per 1 beneficiary), $x_{34}$ - Axis 1 . Action 142. Forest agricultural producer groups (PLN per 1 beneficiary), $x_{35}$ - Axis 2 . Action 226. Restoring forestry production potential damaged by disasters and introducing forest prevention instruments (PLN per 1 beneficiary), $x_{36}$-Axis 3 . Action $313,322,323$. Renovation and development of forest villages (PLN per 1 beneficiary), $x_{37}$ - Axis 4 . Action 413. Implementation of local forest development strategies (PLN per 1 beneficiary), $x_{38}$-Axis 4 . Action 421. Implementation of forest cooperation projects (PLN per 1 beneficiary), $x_{39}-$ Axis 4 . Action 431. Functioning of the local action group, skills acquisition and forest activation (PLN per 1 beneficiary).
The $X_{10}$ variable is considered to be an inhibitor, while the others are considered to be stimuli.

For selected variables, statistical characteristics, which are presented in Table 1, were defined. They present disproportions between particular voivodeships, which were illustrated by means of minimum and maximum values and the coefficient of variation, recorded in particular voivodeships. The coefficient of variation of characteristics describing the level of local development ranged from approx. 13 to $138 \%$. The highest diversity was recorded in the variables characterising the share of perennial crops according to the new definition in the total area of the voivodeship $(V=138 \%)$. The smallest one occurred in the case of the variable describing the average usable area of a flat for which the coefficient of variation was equal to $V=13 \%$.

As regards the variables describing the level of use of EU funds (Table 2), the highest variability was recorded in relation to Axis 1. Action 133. Information and promotion activities $(V=362 \%)$, and the

Table 1. Statistical characteristics of diagnostic variables characterising individual voivodships from the point of view of local development

\begin{tabular}{|c|c|c|c|c|c|}
\hline Variable & Mean & Minimum & Maximum & Standard deviation & $\begin{array}{c}\text { Coefficient of } \\
\text { variation } \\
(\%)\end{array}$ \\
\hline$x_{1}$ & 1.06 .2025 & 1.7 (Podkarpackie) & 20.8 (Wielkopolskie) & 1.05 .1985 & 94 \\
\hline$\ldots$ & $\ldots$ & $\ldots$ & $\ldots$ & $\ldots$ & $\ldots$ \\
\hline$x_{27}$ & 86.64 & 41.79 (Lubuskie) & 143.67 (Małopolskie) & 25.52 & 29 \\
\hline
\end{tabular}

Source: own elaboration based on data from Local Data Bank GUS (2016).

Table 2. Statistical characteristics of diagnostic variables characterising particular voivodeships in terms of the level of use of UE funds under RDP 2014-2020

\begin{tabular}{|c|c|c|c|c|c|}
\hline Variable & Mean & Minimum & Maximum & Standard deviation & $\begin{array}{c}\text { Coefficient of } \\
\text { variation } \\
(\%)\end{array}$ \\
\hline$X_{28}$ & 2062 & $\begin{array}{c}1461 \\
\text { (Zachodniopomorskie) }\end{array}$ & 2881 (Mazowieckie) & 421 & 20 \\
\hline$\ldots$ & $\ldots$ & $\ldots$ & $\ldots$ & $\ldots$ & $\ldots$ \\
\hline$X_{39}$ & 1216959 & 997071 (Podlaskie) & 1604126 (Lubuskie) & 154464 & 13 \\
\hline
\end{tabular}

Source: own elaboration based on data from the Local Data Bank GUS (2015). 
smallest variability for Action 121 . Modernisation of agricultural holdings in forests $(V=11 \%)$.

\section{RESULTS AND DISCUSSION}

\section{Classification on Hellwig's development model method}

To determine the level of local development of the voivodeships, Hellwig's development model method was used, which was described in detail in the following publications: Kamińska and Janulewicz (2009); Adamowicz and Janulewicz (2012, 2016); Bujanowicz-Haraś et al. (2015); Janulewicz and Bujanowicz-Haraś (2016).

As research shows, Group I, with the highest level of local development, includes only 2 voivodeships (Mazowieckie and Wielkopolskie). The second group turned out to be the most numerous and concentrated 6 voivodeships: Pomorskie, Dolnośląskie, Śląskie, Opolskie, Lubuskie and Kujawsko-Pomorskie. The third group consisted of 5 voivodeships: Zachodniopomorskie, Łódzkie, Podkarpackie, Małopolskie and Lubelskie. Whereas, voivodeships characterised by the weakest local development (group IV) included only three entities: Warmińsko-Mazurskie, Podlaskie and Świętokrzyskie.

Taking into account investment outlays in the private sector, it can be noted that they are much higher (PLN 6,229) in Group I (with the highest level of local development) and the lowest (PLN 2,536) in Group IV (with the lowest level of local development). The same dependencies can be observed for the following characteristics: gross value of fixed assets per capita (PLN 120,180 - Group I, PLN 75,787 - Group IV), registered unemployment (5.95 to $11.77 \%$ ) or gas consumption in households $\left(144 \mathrm{~m}^{3}\right.$ to $57 \mathrm{~m}^{3}$ for Group IV). The reverse situation can be observed with regard to the average usable area per capita, which is the lowest $\left(91.5 \mathrm{~m}^{2}\right)$ in voivodships classified in Group I, and the highest $\left(103.2 \mathrm{~m}^{2}\right)$ in Group IV.

Table 3. Classification based on the values of partial synthetic measure describing the level of local development of voivodeships

\begin{tabular}{|c|c|c|l|}
\hline $\begin{array}{c}\text { Group } \\
\text { number }\end{array}$ & $\begin{array}{c}\text { The number } \\
\text { of countries in } \\
\text { the group }\end{array}$ & $\begin{array}{c}\text { The level of } \\
\text { measurement }\end{array}$ & \multicolumn{1}{|c|}{ The member voivodeships } \\
\hline I & 2 & Above 0.3799 & Mazowieckie (0.4704), Wielkopolskie $(0.4502)$ \\
\hline II & 6 & $\begin{array}{c}\text { From } 0.2850 \\
\text { to } 0.3798\end{array}$ & $\begin{array}{l}\text { Pomorskie }(0.3606), \text { Dolnośląskie }(0.3466), \text { Śląskie }(0.32545), \text { Opolskie } \\
(0.32529), \text { Lubuskie }(0.29818), \text { Kujawsko-Pomorskie }(0.2952)\end{array}$ \\
\hline III & 5 & $\begin{array}{c}\text { From } 0.1899 \\
\text { to } 0.2849\end{array}$ & $\begin{array}{l}\text { Zachodniopomorskie }(0.2831), \text { Lódzkie }(0.27043), \text { Podkarpackie } \\
(\text { (0.22438), Małopolskie }(0.21226), \text { Lubelskie }(0.20315)\end{array}$ \\
\hline IV & 3 & Blow 0.1899 & $\begin{array}{l}\text { Warmińsko-Mazurskie }(0.18703), \text { Podlaskie }(0.16808), \text { Ś Siętokrzyskie } \\
(0.13856)\end{array}$ \\
\hline
\end{tabular}

Source: own elaboration based on data from the Local Data Bank GUS (2016).

Table 4. Average values of the variables determining the level of local development

\begin{tabular}{|c|c|c|c|c|c|}
\hline Specification & Group I & Group II & Group III & Group IV & Total average \\
\hline$x_{1}$ & 20.15 & 4.05 & 4.22 & 4.77 & 6.25 \\
\hline$\ldots$ & $\ldots$ & $\ldots$ & $\ldots$ & $\ldots$ & $\ldots$ \\
\hline$x_{27}$ & 111 & 81 & 94 & 69 & 87 \\
\hline
\end{tabular}

Source: own elaboration based on data from the Local Data Bank GUS (2016). 
Proceedings of the 2018 International Scientific Conference 'Economic Sciences for Agribusiness and Rural Economy' No 1, Warsaw, 7-8 June 2018, pp. 376-382

\section{The impact of EU funds on local development}

According to the conducted research (Table 5), significant statistical dependencies can only be noted for two characteristics: Axis 1. Action 114. The use of advisory services by farmers and forest holders is correlated with the voivodeship's share in the production of slaughter livestock (0.75) and Axis 4. Action 421. Implementation of cooperation projects with the number of kilometres of railroads per 10 thousand residents $(0.76)$.

\section{Cluster analysis by the Ward method}

According to the conducted research (Fig. 1), Group A included only one voivodeship (Świętokrzyskie), which in Hellwig's model method was classified to group IV (with the lowest level of local development). Group B also included only one voivodeship - Podkarpackie, which represented Group III according to Hellwig's method. Group C also comprised only one voivodeship - Mazowieckie, which in Hellwig's method was classified to Group I (with the highest

Table 5. Correlations between the value of the selected financial fund measures used under the RDP 2014-2015 and selected factors characterizing local development

\begin{tabular}{|c|c|c|}
\hline Variables & $x_{29}$ & $x_{39}$ \\
\hline$x_{1}$ & $\mathbf{0 . 7 5}$ & -0.03 \\
\hline$x_{21}$ & -0.23 & $\mathbf{0 . 7 6}$ \\
\hline
\end{tabular}

Source: own study based on data from the BDL 2015-2016 GUS.

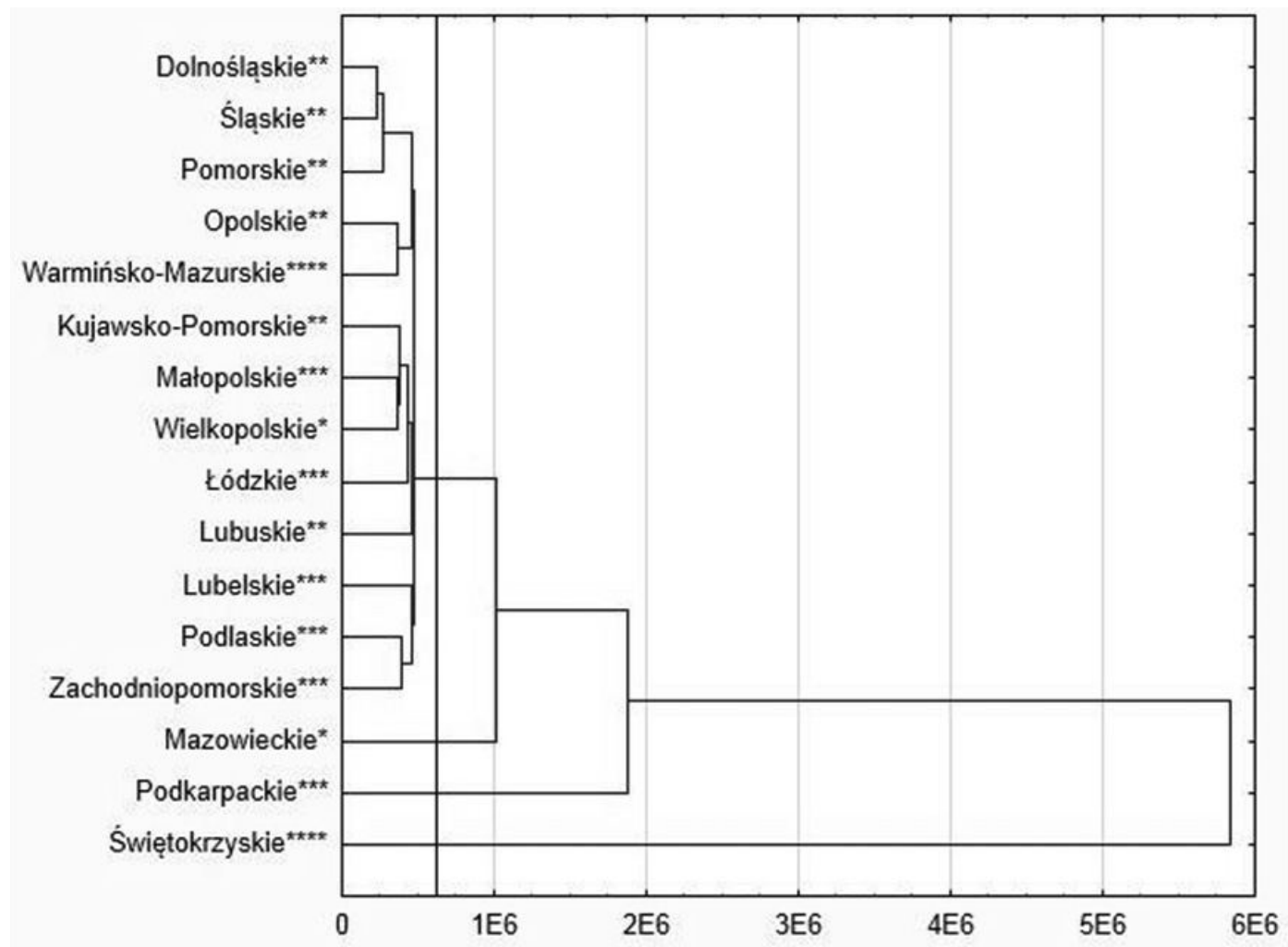

Figure 1. Breakdown of voivodeships by the WARDA method from a level of use of EU funds perspective $\left({ }^{*}\right.$ number means the group into which the commune was classified using Hellwig's method)

Source: own elaboration using Statistica 13 software. 
level of local development). Group D turned out to be the most numerous, comprising 13 voivodeships, one of which represented the group with the highest level of local development (Wielkopolskie), 6 voivodeships belonging to Group II, 5 voivodeships belonging to Group III and one to Group IV.

\section{CONCLUSIONS}

The results of the research allowed to determine the level of local development in 16 voivodeships in Poland. The use of the taxonomic method (Hellwig's development model) made it possible to classify individual voivodeships to one of four groups from a local development level perspective. Group I (with the highest level) included 2 voivodeships: Mazowieckie and Wielkopolskie. The second group consisted of 6 voivodeships: Pomorskie, Dolnośląskie, Śląskie, Opolskie, Lubuskie and Kujawsko-Pomorskie. The third group consisted of 5 voivodeships: Zachodniopomorskie, Łódzkie, Podkarpackie, Małopolskie and Lubelskie. Whereas, among the voivodeships characterised by the lowest level of local development (Group IV) were three voivodeships: Warmińsko-Mazurskie, Podlaskie and Świętokrzyskie. When analysing the average values of particular variables characterising the level of local development in voivodeships with the highest level of local development, it can be observed that for 7 variables (out of 27) they are the most favourable (highest for the stimuli and lowest for the inhibitors), and in comparison with the total average (calculated for all voivodeships), the average values of Group I are higher for 19 variables.

The direct impact of EU funds could only be distinguished in relation to two variables: Action 114. Use of advisory services by farmers and forest holders, which was correlated $(0.75)$ with the voivodeship's share in the production of slaughter livestock and Action 421. Implementation of cooperation projects with the number of kilometres of railroads per 10 thousand residents for which the correlation coefficient amounted to 0.76 .

In the Ward cluster analysis, it can be noted that Groups A, B and C consisted of one voivodeship each representing a different level of local development, while group D was the most numerous and mainly consisted of entities classified to Groups II and III.

The methods used showed a disproportion between local development and use of EU funds. The obtained results confirm the usefulness of synthetic measures in assessing the level of local development. At the same time, limitations in the interpretation of test results should be borne in mind.

\section{REFERENCES}

1. Adamowicz, M., Janulewicz, P. (2012). Wykorzystanie metod wielowymiarowych w określeniu pozycji konkurencyjnej gminy na przykładzie województwa lubelskiego. Metody Ilościowe w badaniach ekonomicznych [The use of multidimensional methods in determining the competitive position of the commune on the example of the Lubelskie Voivodeship. Quantitative methods in economic research.]. Vol. 13. Wydawnictwo SGGW, Warszawa.

2. Adamowicz, M., Janulewicz, P. (2016). Ocena poziomu rozwoju dużych miast w Polsce - wyniki badań wykorzystujących wzorzec rozwoju Hellwiga [Assessment of the level of development of large cities in Poland - results of research using Hellwig's development pattern]. Studia Regionalne i Lokalne, 2 (64), pp. 68-86.

3. Brzózka, M., Nurzyńska, I. (2002). Wspólna Polityka Rolna Unii Europejskiej a polskie rolnictwo. Rozważania o korzyściach i kosztach [Common Agricultural Policy of the European Union and Polish agriculture. Considerations about benefits and costs]. UKIE, Warszawa.

4. Bujanowicz-Haraś, B., Janulewicz, P., Nowak, A., Krukowski, A. (2015). Evaluation of sustainable development in the member states of the European Union. Problemy Ekorozwoju, 10 (2), pp. 71-78.

5. Janulewicz, P., Bujanowicz-Haraś, B. (2016). Ocena rozwoju zrównoważonego polskich podregionów [Evaluation of sustainable development of Polish subregions]. Roczniki Naukowe SERiA, 18 (2), pp. 114$-119$.

6. Janulewicz, P., Kamińska, A., Białoskurski, S. (2016). Analiza podobieństwa wybranych państw Unii Europejskiej z punktu widzenia rozwoju zrównoważonego przy wykorzystaniu metody Warda [Analysis of the similarity of selected European Union countries from the point of view of sustainable development using the Ward method]. Roczniki Naukowe SERiA,18 (1), pp. 78-83. 
7. Kamińska, A., Janulewicz, P. (2009). Klasyfikacja gmin wiejskich województwa lubelskiego na podstawie rozwoju społeczno-gospodarczego [Classification of rural communes in the Lubelskie Voivodeship on the basis of socio-economic development]. Folia Pomeranae Universitatis Technologiae Stetinensis. Oeconomica, 57, pp. 31-42.

8. Knieć, W. (2012). Wspólna Polityka Rolna Unii Europejskiej a zrównoważony rozwój obszarów wiejskich Polski. Analiza socjologiczna [Common Agricultural Policy of the European Union and sustainable development of Polish rural areas. Sociological analysis]. Wydawnictwo Naukowe Uniwersytetu Mikołaja Kopernika, Toruń.

9. Misztal, A. (2016). Wpływ unijnej polityki regionalnej na zrównoważony rozwój euroregionów zachodniego pogranicza Polski [The impact of EU regional policy on the sustainable development of the Euroregions of the western border of Poland]. Wydawnictwo Uniwersytetu Łódzkiego, Łodź. Retrieved from: http://dspace. uni.lodz.pl:8080/xmlui/bitstream/handle/11089/22824/ $\% 5 \mathrm{~b} 1 \% 5 \mathrm{~d}-213$ Misztal_Wp\%C5\%82yw\%20unijnej. pdf? sequence $=1 \&$ isAllowed=y [Accessed 31.05.2018].

10. Nowak, A., Janulewicz, P., Krukowski, A. (2016). Zróżnicowanie przestrzenne absorpcji funduszy pomocowych w Polsce w ramach PROW 2007-2013 [Spatial differentiation of absorption of aid funds in Poland under RDP 2007-2013]. Roczniki Naukowe SERiA, 18 (2), pp. 196-201.

11. Nowak, A., Janulewicz, P., Krukowski, A., Bujanowicz-Haraś, B. (2016). Diversification of the level of agricultural development in the member states of the
European Union. Cahiers Agricultures, 25 (5), \# 55004. DOI: $10.1051 /$ cagri/2016040

12. Piworowicz, J. (2015). Wspólna Polityka Rolna i jej wpływ na rozwój rolnictwa w Polsce [Common Agricultural Policy and its impact on the development of agriculture in Poland]. Uniwersytet Warmińsko-Mazurski, Olsztyn. Retrieved from: http://www.uwm.edu.pl/ wne/katedry/kmakro/files/piworowicz_j.pdf [Accessed 15.05.2018].

13. Sawicka, J., Borowy, M. (2007). Działania wspierające ochronę krajobrazu kulturowego i przyrodniczego na przykładzie pilotażowego programu Leader+ [Measures supporting cultural and natural landscape protection in Poland on the example of the Pilot Program Leader+]. Acta Scientiarum Polonorum. Oeconomia, 6 (1), pp. 5-14.

14. Sobczyk, A. (2010). Rozwój lokalny-wybrane problem finansowania [Local development - selected financing problem]. Zeszyty Naukowe SGGW w Warszawie. Ekonomika i Organizacja Gospodarki Żywnościowej, 85, pp. 125-136.

15. Tomczak, F. (2009). Zmiany i reformy WPR: konsekwencje dla rolnictwa i finansowania polityki rolnej [Changes and reforms of the CAP: consequences for agriculture and financing of agricultural policy]. PIB, Warszawa.

16. Wójcik, G. (2011). Wspólna Polityka Rolna i jej wpływ na rozwój rolnictwa i obszarów wiejskich po akcesji w Unii Europejskiej [Common Agricultural Policy and its impact on the development of agriculture and rural areas after accession in the European Union] Wiadomości Zootechniczne, 49 (2), pp. 61-68. 